\title{
PROWENIENCJE ZESPOŁU DOKUMENTÓW PERGAMINOWYCH BIBLIOTEKI NAUKOWEJ PAU I PAN W KRAKOWIE
}

Zbiór dokumentów pergaminowych Biblioteki Naukowej PAU i PAN w Krakowie jest dobrze znany. Pierwszy spis 330 dokumentów pergaminowych i papierowych opublikował już w r. 1912 Jan Czubek w dodatku do Katalogu rękopisów AU ${ }^{1}$. Ponad pół wieku później ukazał się trzyczęściowy Katalog dokumentów pergaminowych, opracowany przez Kazimierza Dziwika według aktualnie obowiązujących wskazówek i wytycznych ${ }^{2}$.

Niewiele natomiast wiadomo na temat samych dziejów tej kolekcji. Obaj autorzy marginalnie potraktowali kwestie proweniencji, wymienili bowiem tylko tych ofiarodawców, których imiona i nazwiska wypisane były na odwrocie dyplomów. Nie sięgnęli natomiast do wiadomości zawartych w dziennikach podawczych Towarzystwa Naukowego Krakowskiego i Akademii Umiejętności, księgach darów czy do zestawień ofiarodawców publikowanych w „Roczniku TNK” oraz corocznych sprawozdaniach sekretarza generalnego Akademii ${ }^{3}$. Informacje z tych źródeł zebrała i zestawiła Bogumiła Schnaydrowa, lecz wymieniła jedynie nazwiska darczyńców nie dokonując identyfikacji ich darów ${ }^{4}$. Nie wyróżniła też osobno ofiarodawców

${ }^{1}$ J. Czubek, Katalog rękopisów Akademii Umiejętności w Krakowie. Dodatek, Kraków 1912, s. $54-145$.

${ }^{2}$ K. Dziwik, Katalog dokumentów pergaminowych Biblioteki PAN w Krakowie, cz. I, Dokumenty z lat 1113-1571, cz. II, Dokumenty z lat 1573-1787, cz. III, Dokumenty z lat 1403-1797, Wrocław-Warszawa-Kraków 1966-1970.

${ }^{3}$ Archiwum Nauki PAN i PAU w Krakowie (dalej: Arch. Nauk. PAN i PAU), Dziennik podawczy TNK, sygn. TNK 28-29 (dawna sygn. TNK 44-45); Dziennik podawczy AU/PAU; Biblioteka Naukowa PAU i PAN w Krakowie (dalej: Bibl. Nauk. PAU i PAN) rkps 3697, 9414 i bez sygn.; Dary złożone [...] od dnia 25 lutego 1858 do 20 lutego 1859 na ręce sekretarza Towarzystwa, Kraków 1859; Dodatek do „Rocznika Towarzystwa Naukowego Krakowskiego” za okres 1860-1861, Kraków 1863.

${ }^{4}$ B. Schnaydrowa, Ofiarodawcy Towarzystwa Naukowego Krakowskiego. Z badań nad proweniencja zbiorów Biblioteki PAN w Krakowie, „Rocznik Biblioteki PAN” (dalej: „Rocznik”), R. 21: 1975, s. 99-132; Taż, Ofiarodawcy Akademii Umiejętności 1873-1919. Z badań nad proweniencja zbiorów Biblioteki PAN w Krakowie, „Rocznik”, R. 26: 1981, s. 11-42. 
dyplomów pergaminowych, lecz zaliczyła ich do szerszej grupy osób, które wzbogaciły zbiory o materiały rękopiśmienne.

Uzasadniając przed laty konieczność i celowość prowadzenia badań proweniencyjnych Bogumiła Schnaydrowa pisała, że zapiski własnościowe „stanowią cenny materiał źródłowy do historii kultury i życia umysłowego narodu w minionych wiekach, a także przyczyniają się do poznania dziejów kolekcjonerstwa, rozpowszechnionego w Polsce szczególnie szeroko po klęsce rozbiorów i upadku państwowości" ${ }^{5}$. Zasadne wydaje się poszerzenie kwestionariusza badawczego o informacje na temat wielkości i formy przekazywanych darów oraz pobudek, jakie kierowały ofiarodawcami tudzież okoliczności, w jakich do nich doszło. Dopiero wówczas otrzymamy pełną odpowiedź na pytanie, jak kształtował się mecenat społeczeństwa polskiego wobec instytucji naukowych takich jak TNK, a potem AU/PAU, w drugiej połowie XIX i w XX w.

Powstałe w r. 1815 Towarzystwo Naukowe Krakowskie przy Uniwersytecie Krakowskim początkowo nie gromadziło własnych zbiorów, a wszystkie otrzymane dary i legaty przekazywało do zbiorów uniwersyteckich. Dopiero w r. 1850 TNK podjęło uchwałę inicjującą powstanie własnych zbiorów bibliotecznych. Przez kolejnych kilka lat krystalizowała się koncepcja, jaki mają one przyjąć profil. Początkowo zdecydowano, że Towarzystwo będzie gromadzić jedynie dublety pozycji, które Biblioteka Jagiellońska posiadała już w swoim zasobie, a pozostałe materiały w dalszym ciągu będą oddawane do zbiorów uniwersyteckich. Ostatecznie problem podziału majątkowego z Uniwersytetem rozwiązany został w r. 1856, gdy Towarzystwo otrzymało nowy statut, który nadawał mu całkowitą samodzielność organizacyjną i majątkową. Odtąd wszystkie nowe nabytki, czy to pochodzące z darów, czy też z zakupów, pozostawały w wyłącznej dyspozycji Towarzystwa. Nie posiadało ono jednak własnego lokalu, więc w dalszym ciągu część nabytków przekazywano za rewersami do zbiorów uniwersyteckich, a część deponowano w domu Pawła Popiela przy ulicy Św. Jana $20^{6}$. Było to rozwiązanie tymczasowe. Konieczne było pozyskanie własnego lokalu, w którym Towarzystwo mogłoby odbywać posiedzenia oraz gromadzić i udostępniać zbiory. W r. 1857 z inicjatywy prezesa Towarzystwa, Franciszka Wężyka i dzięki ofiarności społeczeństwa rozpoczęto budowę siedziby przy ulicy Sławkowskiej.

W ciągu ponad czterdziestu lat działalności TNK zyskało nie tylko rozpoznawalność w środowisku krakowskim, lecz urosło do roli głównego animatora życia umysłowego miasta. Prowadziło bowiem nie tylko rozległą działalność badawczą, wydawniczą i popularyzatorską, ale także inicjowało różne projekty, między innymi inwentaryzacji zabytków, czy też ważne dla Krakowa prace konserwatorskie. Duży rozgłos przyniosło otwarcie w 1858 r., przygotowanej przez Towarzystwo wystawy starożytności, która była tłumnie odwiedzana przez zwiedzających.

${ }^{5}$ B. Schnaydrowa, Ofiarodawcy TNK, s. 99.

${ }^{6}$ K. Stachowska, Dzieje budowy Domu Towarzystwa Naukowego Krakowskiego $w$ latach 1857-1866, „Rocznik”, R. 12: 1966, s. 25-78. 
To wszystko sprawiało, że apele o przekazywanie na rzecz Towarzystwa druków, a także pamiątek kultury piśmienniczej i materialnej spotykały się z przychylnym odzewem społeczeństwa.

W 1859 r. Bogumił Gebhardt, ajent generalny Austriackiego Towarzystwa Ubezpieczeń, przekazał do zbiorów TNK cztery dokumenty królewskie z lat 1660-1697 dotyczące posiadania praw własności rodziny Szarysów do młyna w Zielonkach ${ }^{7}$. Towarzystwo podjęło też intensywne starania o pozyskanie nowych nabytków. Ich efektem było przyjęcie w depozyt od Magistratu miasta Krakowa akt i ruchomości nieistniejących krakowskich cechów kurdybaników i pasamoników. Dnia 23 i 24 stycznia 1860 r. w księdze darów TNK zarejestrowano, że władze miasta oddały w depozyt m.in. „8 ksiąg pisanych” cechu kurdybaników i 8 ksiąg protokołów pasamoników oraz 14 przywilejów kurdybaników i 13 pasamoników ${ }^{8}$. W istocie depozyt zawierał: osiem dokumentów pergaminowych cechu kurdybaników z lat 1588-1822 ${ }^{9}$, cztery dokumenty powiązanych z nim cechów: czerwonoskórników, garbarzy, garbarzy czerwonych i skórników ${ }^{10}$, dziewięć dokumentów pergaminowych cechu pasamoników z lat 1614-1676 i cztery dokumenty papierowe tegoż cechu z lat 1614-1617 ${ }^{11}$. W kolejnych latach dzięki ofiarności społeczeństwa zasób dokumentów pergaminowych Biblioteki Towarzystwa systematycznie się powiększał. W marcu 1860 r. ks. Wiktor Pawłowski, proboszcz w Kościelcu, przysłał do zbiorów TNK: „13 monet srebrnych, 5 monet miedzianych oraz dokument z r. 1718 wydany dla Jacka Augusta Łopackiego" ${ }^{12}$. W następnym roku dzięki darom dwóch krakowskich mieszczan Biblioteka wzbogaciła się o sześć dyplomów: Józef Wojciechowski przekazał do jej zborów cztery dokumenty ze zlikwidowanego w wyniku reformy józefińskiej klasztoru karmelitów w Wiśniczu ${ }^{13}$, a Kasper Bielecki dwa dokumenty z r. 1641 i $1669^{14}$. Rok później na listę darczyńców TNK wpisał się ks. Feliks Dymnicki, katecheta gimnazjalny z Rzeszowa i działacz społeczny, który przesłał dyplom Zygmunta Augusta dla miasta Pilzna ${ }^{15}$. Pomimo trudności lokalowych Towarzystwa Magistrat miasta Krakowa 13 października 1862 r. podjął uchwałę o przekazaniu w depozycie do zbiorów TNK akt i ruchomości po nieistniejącym cechu farbiarzy, barchanników i tkaczy krakowskich. Pięć dni później odbiór depozytu odnotowano w księdze darów TNK ${ }^{16}$. Wśród archiwaliów cechowych znalazło się pięć dyplomów z lat 1525-1697 ${ }^{17}$. W 1863 r. Feliks Jaworski ofiarował dokument

\footnotetext{
${ }^{7}$ Bibl. Nauk. PAU i PAN, dok. 251, 259, 266, 285.

${ }^{8}$ Bibl. Nauk. PAU i PAN, rkps 3697, k. 12.

9 Bibl. Nauk. PAU i PAN, dok. 179, 188, 193, 209, 261, 268, 302, 322.

${ }^{10}$ Bibl. Nauk. PAU i PAN, dok. 169, 189, 237, 289.

${ }^{11}$ Bibl. Nauk. PAU i PAN, dok. 197-200, 204-206, 214, 215, 239, 248, 258, 265.

12 Bibl. Nauk. PAU i PAN, rkps 3697, k. 14v; dok. 291.

13 Bibl. Nauk. PAU i PAN, rkps 3697, k. 28; dok. 203, 222, 267, 283.

${ }_{14}$ Bibl. Nauk. PAU i PAN, rkps. 3697, k. 32; dok. 234, 260.

${ }^{15}$ Bibl. Nauk. PAU i PAN, rkps 3697, k. 36; dok. 164.

${ }^{16}$ Bibl. Nauk. PAU i PAN, rkps 3697, k. 41v.

${ }^{17}$ Bibl. Nauk. PAU i PAN, dok. 115, 160, 230, 231, 287.
} 
pergaminowy z r. $1452^{18}$. Znacznie większym nabytkiem był dar znanego krakowskiego bibliofila i kolekcjonera, członka TNK, Jana Wincentego Smoniewskiego, który przekazał „15 sztuk dokumentów i dyplomów z podpisami królów polskich i dygnitarzy" ${ }^{19}$. Niestety lakoniczność adnotacji w księdze darów nie pozwala ustalić, które dokumenty pochodzą z tego daru. Żadnej wątpliwości interpretacyjnych nie pozostawia natomiast zapis, informujący o dyplomie z r. 1689 nadesłanym na adres Towarzystwa przez Władysława Dąmbskiego z Wojnicza ${ }^{20}$.

W 1865 r. nowa siedziba Towarzystwa przy ul. Sławkowskiej była już częściowo wykończona tak, iż 4 marca tego roku mogło się w nim odbyć pierwsze publiczne posiedzenie TNK. W sprawozdaniu przedstawionym wówczas prezes Józef Majer wymienił zgromadzone przez Towarzystwo zbiory, wśród których było 120 dyplomów ${ }^{21}$. Następne dwa lata zajęło przenoszenie zbiorów bibliotecznych oraz muzealnych do własnego gmachu.

Pomyślne sfinalizowanie budowy okazałej siedziby przysporzyło Towarzystwu nowych darczyńców. Kilka miesięcy po inauguracji prac w nowym lokalu przy ul. Sławkowskiej Towarzystwo otrzymało od generała Józefa Bonawentury Załuskiego, uczestnika powstania listopadowego i publicysty cenny dar w postaci dwóch dyplomów ${ }^{22}$. Rok później zbiory dyplomów TNK powiększyły się o dary dwóch krakowskich mieszczan, Sylwery Wolański przekazał siedem dokumentów, w tym pięć dokumentów papierowych z XVIII w., jeden dokument pergaminowy i jeden drukowany ${ }^{23}$, natomiast Wilhelm Ilming podarował dyplom cesarza Franciszka I z r. 1831. Forma zewnętrzna dokumentu cesarskiego tak bardzo przykuła uwagę pisarza prowadzącego księgę darów, że wbrew swojemu dotychczasowemu zwyczajowi pokusił się o zamieszczenie obszerniejszego opisu: „oprawny jako księga z pieczęcią państwa na wosku czerwonym w puszce pozłocistej” ${ }^{24}$. Warto dodać, że Ilming był również ofiarodawcą innych pamiątek na rzecz Towarzystwa, między innymi inkunabułu, zabytków archeologicznych, numizmatów, map i rycin ${ }^{25}$.

Ofiarodawcami TNK byli przedstawiciele różnych grup społecznych i zawodowych, dominowali wśród nich profesorowie uniwersyteccy i członkowie Towarzystwa. Równie często na listę darczyńców wpisywali się mieszczanie krakowscy, urzędnicy, księża, lekarze, publicyści a nawet studenci, nie brakowało też właścicieli ziemskich. W 1866 r. hrabia Feliks Romer, właściciel Inwałdu przekazał do

18 Bibl. Nauk. PAU i PAN, rkps 3697, k. 44; dok. 49.

19 Bibl. Nauk. PAU i PAN, rkps 3697, k. 41v.

${ }^{20}$ Bibl. Nauk. PAU i PAN, rkps 3697, k. 41v; dok. 280.

${ }^{21}$ Zdanie spraw z czynności c.k. Towarzystwa Nauk Krakowskiego $w$ trzech ostatnich latach [...] wd. 4 marca 1865 r. przez Józefa J. Majera, „Rocznik TNK”, t. 34: 1866, s. 20-21.

${ }_{22}$ Bibl. Nauk. PAU i PAN, rkps 3697, k. 51v, 53; dok. 245, 264.

${ }_{23}$ Bibl. Nauk. PAU i PAN, rkps 3697, k. 54.

24 Bibl. Nauk. PAU i PAN, rkps 3697, k. 56v; dok. 326.

${ }^{25}$ Bibl. Nauk. PAU i PAN, rkps 9414, s. 87; Katalog inkunabutów Biblioteki Naukowej PAU i PAN w Krakowie, oprac. T. Dąbrowa, E. Knapek, J Wojtowicz, Kraków 2015, poz. 57. 
zbiorów Towarzystwa dwa dyplomy królewskie z r. 1506 i $1554^{26}$. Zapewne wysoka pozycja społeczna ofiarodawcy sprawiła, że informację o tym darze odnotowano nie tylko w Księdze darów TNK, lecz stosowną notkę zamieszono także na odwrocie obu dokumentów. W r. 1867 Biblioteka TNK wzbogaciła się o kilka kolejnych dyplomów. Dwa dokumenty do jej zbiorów przekazał Felicjan Laskowski, właściciel dóbr Bażanówka i Ladzin, wiceprezes Towarzystwa Kredytowego Galicyjskiego i poseł na sejm krajowy ${ }^{27}$. Niestety ofiarowanych przez niego dokumentów nie udało się zidentyfikować. Jeden dokument ofiarował Stanisław Krzyżanowski z Czerpowodów ${ }^{28}$. W następnych latach przekazał on do zbiorów Towarzystwa jeszcze 15 dokumentów pergaminowych i dużą kolekcję dokumentów papierowych ${ }^{29}$. Ofiarowane przez niego dokumenty i rękopisy opatrzone są w pieczątkę własnościową: „Księgozbiór Krzyżanowskich w Czerpowodach”.

Początkowo nie wydzielano dokumentów pergaminowych ze zbiorów i spuścizn, w których trafiły do Biblioteki Towarzystwa, lecz przechowywano je łącznie $\mathrm{z}$ innymi materiałami rękopiśmiennymi. $\mathrm{W}$ ten sposób zostały też opisane w pierwszym drukowanym katalogu zbiorów rękopiśmiennych TNK, opracowanym w 1869 r. przez Władysława Seredyńskiego ${ }^{30}$.

Dnia 15 lutego 1870 r. znany krakowski malarz, Izydor Jabłoński przekazał do zbiorów TNK dyplom z pieczęcią Augusta II z 1697 r. ${ }^{31}$ Trzy dni później w księdze darów zarejestrowano darowiznę Urszuli z Sołtyków Wielogłowskiej, siostry biskupa Kajetana Sołtyka, wdowy po Kasprze Wielogłowskim, która oddała do zbiorów TNK dyplom wydany przez Jana Kazimierza dla miasta Chęciny ${ }^{32}$. W drugiej połowie tego roku nieznany bliżej J. Tomak za pośrednictwem Antoniego Sozańskiego oddał do zbiorów Towarzystwa dokument wystawiony przez króla Michała Korybuta Wiśniowieckiego ${ }^{33}$. Niestety skrótowość zapisu w księdze darów nie pozwala na identyfikację tego dokumentu.

W r. 1871 zaczęły nadchodzić do Towarzystwa dary przeznaczone na rzecz organizującej się Akademii Umiejętności. Z taką intencją w październiku $1871 \mathrm{r}$. Maksymilian Witkowski oddał na ręce podskarbiego TNK trzy dokumenty, w tym jeden wydany przez króla Jana III Sobieskiego ${ }^{34}$. Dwa lata później przyniósł jeszcze jeden dokument, wystawiony przez przeora franciszkanów o. Remigiusza

${ }^{26}$ Bibl. Nauk. PAU i PAN, rkps 3697, k. 56; dok. 146, 159.

${ }^{27}$ Bibl. Nauk. PAU i PAN, rkps 3697, k. 62v.

${ }^{28}$ Bibl. Nauk. PAU i PAN, rkps 3697, k. 62v; dok. 30.

${ }^{29}$ Bibl. Nauk. PAU i PAN, dok. 89, 94, 97, 110, 129, 140, 174-176, 240, 271, 334, 342, 377, 380.

${ }^{30}$ W. Seredyński, Rękopismy Towarzystwa Naukowego Krakowskiego systematycznie zestawione, Kraków 1868.

${ }^{31}$ Bibl. Nauk. PAU i PAN, rkps 3697, k. 69v; dok. 284.

${ }^{32}$ Bibl. Nauk. PAU i PAN, rkps 3697, k. 69v; dok. 243.

${ }^{33}$ Bibl. Nauk. PAU i PAN, rkps 3697, k. 70v

${ }^{34}$ Bibl. Nauk. PAU i PAN, rkps 3697, k. 71v. 
Zawadzkiego dla Piotra Prebendowskiego ${ }^{35}$. W przypadku ostatniego z wymienionych dokumentów niestety nie wiadomo, czy chodziło o dokumenty pergaminowe czy papierowe.

W 1873 r. TNK przekształciło się w Akademię Umiejętności. Zmianie uległa struktura organizacyjna i charakter samego stowarzyszenia, które stało się korporacją uczonych mającą na celu wyznaczanie nowych kierunków badawczych oraz realizowanie dużych projektów o znaczeniu ogólnopolskim. Rozszerzenie zakresu działalności nadało Akademii zasięg ponadzaborowy, co znacznie powiększyło krąg potencjalnych ofiarodawców. Niebawem jej zbiory wzbogaciły się o nowe nabytki.

W 1873 r. znany warszawski bibliofil i kolekcjoner, Cyprian Walewski zapisał w testamencie AU całe swoje zbiory, które zawierały bogatą bibliotekę liczącą ponad 10 tys. druków oraz kolekcje: rękopisów, dokumentów pergaminowych i papierowych, map, rycin, medali oraz monet ${ }^{36}$. Dwa lata później Władysław Walewski, brat Cypriana i wykonawca jego testamentu dokonał formalnego przekazania zbiorów. Kolekcja dyplomów Cypriana Walewskiego składała się z 34 dokumentów pergaminowych i 24 dokumentów papierowych ${ }^{37}$.

Niektórzy ofiarodawcy przekazywali do zbiorów Akademii dokumenty, które stanowiły część ich archiwum rodzinnego i często były traktowane jako osobiste pamiątki. Tak postąpił między innymi Seweryn Waxman, który 6 listopada $1873 \mathrm{r}$. oddał do zbiorów Akademii dokument nobilitacyjny swojego przodka Jana Waxmana z r. $1589^{38}$. Niecodzienne okoliczności poprzedziły przekazanie do Akademii rękopisów dotyczących wsi Jazowska. Po bezpotomnej śmierci Ludwika Wyszkowskiego, w r. 1874 wieś tę nabył w spadku Stanisław Fihauser. Wkrótce jednak postanowił odsprzedać ją żydowskiej spółce meblowej „Ader et Robinson” ${ }^{39}$. Negocjując kontrakt postanowił, że lepszym rozwiązaniem będzie przekazanie do zbiorów AU księgi sądowej wsi Jazowska $z$ lat 1663-1754 oraz dokumentu granicznego tejże wsi z r. $1565^{40}$, niż oddanie ich nowym właścicielom.

Hojnymi ofiarodawcami na rzecz Akademii byli jej członkowie. Oskar Kolberg wśród licznych darów rękopiśmiennych do zbiorów Biblioteki AU oddał również dwa dyplomy pergaminowe. Dnia 20 czerwca 1876 r. w księdze darów AU wpisano, że przekazał dwa dokumenty pergaminowe, jeden wystawiony przez papieża Sykstusa IV, a drugi przez króla Zygmunta Augusta ${ }^{41}$. W lipcu 1877 r. ks. Antoni Brykczyński, profesor w Seminarium Duchownym w Płocku, członek komisji

${ }^{35}$ Bibl. Nauk. PAU i PAN, rkps 9414, k. 7.

${ }^{36}$ B. Paloc-Schnaydrowa, Cyprian Walewski. Bibliograf $i$ kolekcjoner (1820-1873), „Rocznik", R. 4: 1958, s. 378.

${ }^{37}$ Dary złożone Akademii w r. 1875, „Rocznik zarządu AU 1875”, s. 94.

${ }_{38}$ Bibl. Nauk. PAU i PAN, rkps 9414, s. 5; perg. 183; E. Heleniu sz, Wspomnienia lat minionych, t. 1, Kraków 1876, s. 440.

${ }^{39}$ M. Kurzeja-Świątek, Rodzina Skąskich w Sądecczyźnie, „Rocznik Sądecki”, R. 35: 2007, s. 236.

${ }^{40}$ Bibl. Nauk. PAU i PAN, rkps 9414, k. 15, rkps 1552, dok. 168.

${ }^{41}$ Bibl. Nauk. PAU i PAN, rkps 9414, s. 40; dok. 333, 393. 
archeologicznej AU, przekazał do jej zbiorów sześć dokumentów pergaminowych dotyczących Płocka oraz akta z okresu Księstwa Warszawskiego ${ }^{42}$. Trzy miesiące później przesłał kolejne 26 dyplomów oraz 26 monet srebrnych i 35 monet miedzianych ${ }^{43}$. Trzecia część daru nadeszła w czerwcu 1878 r. i zawierała 27 dokumentów pergaminowych i papierowych ${ }^{44}$. Z kolei czwarta przesyłka z 1879 r. zawierała: jeden dokument pergaminowy, 20 papierowych oraz lustracje wsi płockiego kolegium Jezuitów ${ }^{45}$. Skrótowość i lakoniczność wpisów w księdze darów nie pozwala na pewną identyfikację wszystkich dokumentów z tego daru. Jedynie dokumenty przekazane w trzeciej transzy daru w 1878 r. opieczętowane zostały imienną pieczątką darczyńcy: „ks. A. Brykczyński” ${ }^{46}$.

W r. 1877 nieznany bliżej ks. Tomaszewski przesłał do zbiorów Akademii bullę Innocentego IV wydaną dla biskupstwa krakowskiego ${ }^{47}$. W tym samym roku zbiory Akademii wzbogaciły się jeszcze o dwa autografy króla Jana Kazimierza oraz jakiś bliżej nieokreślony szesnastowieczny dokument, który przekazał krakowski sędzia dr Adam Bogusz ${ }^{48}$. Zapiska w księdze darów nie informuje, jaką formę materialną miały te dokumenty i nie podaje żadnych szczegółów ułatwiających ich identyfikację. Z kolei w 1878 r. ks. Tomasz Jurgowski, proboszcz w Maniowach, ofiarował do zbiorów AU dokument Kazimierza Wielkiego, wydany 14 września 1339 r. transumujący nadanie sołectwa w Szaflarach ${ }^{49}$. Dar ten poświadcza wpis do księgi darów oraz stosowna adnotacja na odwrocie dokumentu ${ }^{50}$.

W latach 1876-1879 Akademia otrzymała w trzech transzach od hrabiego Wandalina Pusłowskiego zbiór rękopisów głównie z XVII i XVIII w. ${ }^{51}$ Wśród owych materiałów rękopiśmiennych zebranych w 41 tomach znalazło się 10 dokumentów pergaminowych z XV-XVII w. ${ }^{52}$

W 1879 r. prawnuk Augusta III Sasa, książę Maurycy Montleart, właściciel dóbr lanckorońskich, przekazał do zbiorów Akademii dwa dyplomy, poświadczające nadanie przez Augusta III Sasa w r. 1759 r. księstwa Kurlandii Karolowi

42 Bibl. Nauk. PAU i PAN, rkps 9414, s. 58.

${ }^{43}$ Bibl. Nauk. PAU i PAN, rkps 9414, s. 62; Dary złożone Akademii w r. 1877, „Rocznik zarządu AU 1877", s. 98.

${ }^{44}$ Bibl. Nauk. PAU i PAN, rkps 9414, s. 72; Dary złożone Akademii w r. 1878, „Rocznik zarządu AU 1878", s. 143.

${ }^{45}$ Dary złożone Akademii w r. 1879, „,Rocznik zarządu AU 1879”, s. 143.

${ }_{46}$ Bibl. Nauk. PAU i PAN, rksp 1586.

${ }^{47}$ Bibl. Nauk. PAU i PAN, rkps 9414, s. 41; dok. 383; B. Schany drowa, Ofiarodawcy Akademii Umiejętności, s. 41 utożsamiła go z ks. Napoleonem Tomaszewskim, proboszczem w Trzemiesznie, kanonikiem poznańskim. Identyfikacja ta nie jest pewna, bowiem ks. Napoleonowi Tomaszewskiemu przypisała również dar ks. Teodora Tomaszewskiego.

${ }^{48}$ Bibl. Nauk. PAU i PAN, rkps 9414, s. 64.

${ }^{49}$ Bibl. Nauk. PAU i PAN, rkps 9414, s. 61; Dary złożone w Akademii w $r$. 1877, ,Rocznik zarządu AU 1877", s. 98.

${ }^{50}$ Bibl. Nauk. PAU i PAN, dok. 7.

${ }^{51}$ Bibl. Nauk. PAU i PAN, rkps 9414, s. 36, 88, 90.

${ }^{52}$ Bibl. Nauk. PAU i PAN, rkps 341, 343; dok. 401, 427. 
Krystianowi Wettynowi ${ }^{53}$. Dokumenty miały formę poszytów oprawnych w aksamit i uwierzytelnionych pieczęcią w metalowej puszce ochronnej; niestety nie udało się ich odnaleźć w zbiorach Biblioteki, brak też jakichkolwiek informacji o ich losach.

W 1893 r. Cezary Haller, właściciel Jurczyc i Radziszowa, ofiarował do zbiorów Akademii dokument Zygmunta III Wazy dla cechu krawców wielickich z r. $1591^{54}$.

W 1903 r. Franciszek Ksawery Wolański, skromny urzędnik skarbowy i wydawca źródeł dyplomatycznych przekazał do zbiorów Akademii swoją spuściznę, która poza dokumentami osobistymi i licznymi odpisami, zawierała również cenną kolekcję rękopisów, dokumentów pergaminowych i papierowych. Aż do wybuchu II wojny światowej spuścizna ta nie została opracowana ani skatalogowana. Prace te podjęto dopiero w latach sześćdziesiątych XX w. ${ }^{55}$ Być może opieszałość w katalogowaniu zbiorów rękopiśmiennych, a potem ich migracja w czasie II wojny światowej do Biblioteki Jagiellońskiej i po zakończeniu wojny ponownie do siedziby PAU przy ul. Sławkowskiej spowodowały, że po latach K. Dziwik był w stanie zidentyfikować jedynie 15 dyplomów z tego daru ${ }^{56}$. Tymczasem Franciszek Wolański przekazał ich aż $40^{57}$.

Na ręce Stanisława Smolki, sekretarza generalnego Akademii w latach 18971902 anonimowy darczyńca przekazał zbiór 42 papieskich dokumentów odpustowych i dyspens z lat 1680-1796. Do jednego dokumentu z tego zbioru przyszyto białą nitką karteczkę z adresem odbiorcy: „Akademia Umiejętności W. P. Profesor Smolka" 58 .

W r. 1904 ks. Teodor Tomaszewski, proboszcz w Małogoszczy przesłał do zbiorów Akademii cztery dokumenty, trzy dotyczące Małogoszczy z lat 1475, 1513 i 1563 oraz dokument Władysława IV dla mieszczan nowobrzeskich z r. $1663^{59}$. W liście do sekretarza generalnego, Bolesława Ulanowskiego, ks. Tomaszewski pisał, że dokumenty te odnalezione zostały podczas prac konserwatorskich prowadzonych przy ołtarzu wielkim w kościele parafialnych w Węglaszynie. Uzasadniając swoją decyzję o przekazaniu tych dokumentów Akademii, argumentował: „szkoda byłaby gdyby uległy zniszczeniu i że im lepiej będzie w zbiorach Akademii, gdzie może kiedy komu się przydadzą niż ukryciu, w jakim dotąd i nie wiadomo jak długo

53 Dary złożone Akademii w r. 1879, „Rocznik zarządu AU 1879”, s. 143.

54 Arch. Nauk. PAN i PAU, Dziennik podawczy AU/PAU 1893, nr 588; Bibl. Nauk. PAU i PAN, dok. 186.

55 Katalog rękopisów sygnatury 2631-2906, oprac. Z. Jabłoński, A. Preissner, B. Schnaydrowa, Wrocław-Warszawa-Kraków 1969, s. 122-150.

56 Bibl. Nauk. PAU i PAN, dok. 350, 357, 370, 395, 404, 409, 411, 413, 429, 437, 439, 441, 448-449, 533, 538.

57 Bibl. Nauk. PAU i PAN, dok. 338-339, 343, 345, 348, 350, 355, 357, 367, 370, 395, 398$399,404,409,411,413,424,429,435,437-438,441,448-449,452,487-488,494,507,529,532-533$, 538, 555, 617-618, 621-622, 627.

58 Bibl. Nauk. PAU i PAN, rkps 1581, k. 41.

59 Sprawozdanie sekretarza generalnego za r. 1904, „Rocznik AU 1904-1905”, s. 112; J. Wiśniew ski, Historyczny opis kościołów, miast, zabytków i pamiątek w Jędrzejowskiem, Majerówka 1930, s. 110, 273; Bibl. Nauk. PAU i PAN, dok. 76, 101, 158, 225. 
i z jakiego powodu zostały" ${ }^{\prime 60}$. W 1904 r. dr Marian Sokołowski przywiózł z podróży naukowej do Petersburga dokument pergaminowy, który otrzymał od studenta petersburskiej Akademii Sztuk Pięknych Adolfa Szyszko-Bohusza z prośbą o oddanie go do zbiorów Akademii ${ }^{61}$.

Jan Czubek, bibliotekarz Akademii przystępując na początku XX stulecia do opracowania Katalogu rękopisów AU wzorem swoich poprzedników nie wyodrębniał dyplomów pergaminowych, lecz skatalogował je łącznie z innymi materiałami rękopiśmiennymi. W ten sposób opisane zostały między innymi: dokumenty stanowiące część kolekcji Wandalina Pusłowskiego, ks. Antoniego Brykczyńskiego ${ }^{62}$, a także zbiory dokumentów notarialnych mieszczan bolońskich z lat 1486-167963, papieskich dyplomów odpustowych i dyspens z lat 1680-1796 $6^{64}$, dokumenty z daru ks. Teodora Tomaszewskiego z Małogoszczy ${ }^{65}$; dyplomy doktorskie Jana Kantego Bartscha z r. 1789 i Józefa Krystiana z r. $1793^{66}$, nominacje na stopnie wojskowe dla księcia Aleksandra Radziwiłła z r. 1818, Justyna Dowgiałły z r. 1826, Aleksandra Wielogłowskiego z r. $1830^{67}$, patent dla Henryka Dembińskiego za wynalazek dotyczący ogrzewania z r. $1854^{68}$. Po ukończeniu, w grudniu 1905 r., prac nad pierwszą częścią Katalogu rękopisów AU J. Czubek przystąpił niezwłocznie do opracowania części dalszej katalogu rękopisów oraz do wyodrębnienia i opisania dyplomów pergaminowych. W sprawozdaniu za r. 1906 sekretarz generalny, Bolesław Ulanowski informował, że Biblioteka Akademii posiada 138 uporządkowanych i skatalogowanych dyplomów oraz dziewięć dokumentów złożonych w depozycie ${ }^{69}$. Wyodrębniając zbiór dyplomów J. Czubek nie był konsekwentny, albowiem włączył do niego zarówno dokumenty pergaminowe, jak i niektóre dokumenty papierowe, a także papirus znajdujący się w zbiorach AU. Do nowo utworzonego zbioru przeniósł również część dokumentów pergaminowych objętych drukowanym katalogiem. Ze zrozumiałych względów nie znalazły się w nim dokumenty, które były współoprawne $\mathrm{z}$ innymi materiałami rękopiśmiennymi. Niezrozumiałe jest natomiast nie uwzględnienie w nim przechowywanych luzem papieskich dyplomów odpustowych i dyspens czy dyplomu doktorskiego Jana Kantego Bartscha, uzyskanego na uniwersytecie bolońskim w r. $1789^{70}$. W r. 1912 Jan Czubek opublikował dodatek do Katalogu rękopisów $A U$, zawierający oraz spis 330 dyplomów. W istocie zbiór zawierał: 309 dokumentów pergaminowych, 20 dokumentów papierowych i jeden papirus. Spi-

\footnotetext{
${ }^{60}$ Arch. Nauk. PAN i PAU, Korespondencja Sekretarza generalnego, sygn. KSG 2838/1904.

${ }^{61}$ Sprawozdanie sekretarza generalnego za r. 1904 „Rocznik AU 1904-1905”, s. 98.

62 J. Czubek, Katalog rękopisów AU, sygn. 343, 343, 1586.

63 Tamże, sygn. 1536.

64 Tamże, sygn. 1581.

65 Tamże, sygn. 1579, 1580 .

66 Tamże, sygn. 1511, 1583.

67 Tamże, sygn. 1584.

68 Tamże, sygn. 1585.

69 Sprawozdanie sekretarza generalnego za r. 1906, „Rocznik AU 1906/1907”, s. 110.

70 J. Czubek, Katalog rękopisów AU, sygn. 1511, 1536, 1581.
} 
sem tym nie zostało natomiast objęte dziewięć dyplomów, które stanowiły depozyt miasta Biała $^{71}$.

Spis 330 dyplomów opublikowany w 1912 r. przez Czubka nie obejmował dokumentów, które wpłynęły do zbiorów Biblioteki w latach 1906-1912. Nie znalazł się w nim na przykład dokument pergaminowy ofiarowany do zbiorów AU przez księcia Tadeusza Lubomirskiego, właściciela Małej Wsi w powiecie grójeckim oraz wsi Zaworów, Lechów i Wolica na Wołyniu, wydawcę Kodeksu Dyplomatycznego Księstwa Mazowieckiego ${ }^{72}$. Długo czekała na opracowanie spuścizna ks. Jana Ambrożego Wadowskiego oddana do zbiorów AU w 1909 r. przez Antoniego Wadowskiego. Wśród materiałów rękopiśmiennych zgromadzonych przez lubelskiego historyka znalazły się dwa dokumenty pergaminowe ${ }^{73}$. W latach 1912-1917 do zbiorów Akademii dwa dokumenty przekazał Fryderyk Zoll, profesor prawa i rektor UJ, wiceprezes $\mathrm{AU}^{74}$.

Pomyślny rozwój Akademii Umiejętności przerwał wybuch I wojny światowej. Z powodu działań wojennych ustała wymiana naukowa, znacznemu ograniczeniu uległ również mecenat, którym społeczeństwo otaczało Akademię. Ofiarność społeczna skierowała się na pomoc ofiarom działań zbrojnych. Po zakończeniu działań wojennych i odzyskaniu przez Polskę niepodległości sytuacja Akademii nie uległa poprawie. Akademia utraciła bowiem dotacje austriackiego rządu i galicyjskiego Sejmu Krajowego, a kryzys finansowy lat dwudziestych doprowadził do znacznego zmniejszenia wartości kapitału własnego. Po odzyskaniu niepodległości wzrosła też liczba instytucji, których zadaniem było gromadzenie zabytków i pamiątek kultury narodowej.

W r. 1923 Stanisław Pęksa, notariusz z Nowego Sącza przekazał do zbiorów PAU 15 dokumentów pergaminowych odnoszących się do Proszowic. Wystawcami byli królowie polscy: Kazimierz Jagiellończyk, Jan Olbracht, Zygmunt I Stary, Zygmunt August, Stefan Batory, Michał Korybut Wiśniowiecki i Jan III Sobieski oraz papież Innocenty $\mathrm{X}^{75}$. Rok później darczyńca dołączył do nich dokument Władysława Jagiełły z 1409 r. oraz osiemnastowieczne kopie dokumentów dotyczących Proszowic $^{76}$. Przed r. 1927 Stanisław Peszko, nauczyciel języka polskiego w gimnazjum w Pińczowie przekazał do zbiorów PAU dokument Augusta III Sasa dla miasta Koszyce z r. 1752 $2^{77}$. O darze tym informuje jedynie ołówkowa notka proweniencyjna zamieszczona na górnej oprawie pergaminowego poszytu ${ }^{78}$.

71 Bibl. Nauk. PAU i PAN, dok. 460, 461, 462, 464, 465, 466, 469.

72 Bibl. Nauk. PAU i PAN, dok. 365.

73 Bibl. Nauk. PAU i PAN, dok. 584-585.

74 Bibl. Nauk. PAU i PAN, dok. 352, 353.

75 Sprawozdanie z czynności PAU od czerwca 1923 do czerwca 1924, „Rocznik PAU 1923-1924”, s. 32-33; Bibl. Nauk. PAU i PAN, dok. 331, 335-337, 354, 356, 403, 414, 426, 454, 476.

76 Sprawozdanie z wydawnictw i czynności PAU od czerwca 1924 do czerwca 1925, „Rocznik PAU 1924-1925”, s. 29; Bibl. Nauk. PAU i PAN, dok. 371.

77 Bibl. Nauk. PAU i PAN, dok. 442.

${ }^{78}$ K. Dziwik, Katalog dokumentów pergaminowych, cz. II, nr 473 błędnie odczytał nazwisko darczyńcy Paszko zamiast Paszek. 
Zapewne w latach trzydziestych XX w. gmina wsi Krościenko Niżne w powiecie krośnieńskim przekazała do zbiorów PAU w depozycie 2 dokumenty z r. 1589 i $1633^{79}$. Niestety, nie zachowała się żadna dokumentacja potwierdzająca przyjęcie tego depozytu.

Zmarły w 1936 r. ks. Jan Fijałek, profesor historii UJ, członek PAU i wieloletni kierownik jej wydawnictwa zapisał $\mathrm{w}$ testamencie Akademii swoje zbiory biblioteczne, kolekcję rękopisów oraz spuściznę rękopiśmienną. W trakcie opracowania materiałów rękopiśmiennych z jego spuścizny odnaleziono dwa piętnastowieczne dokumenty pergaminowe ${ }^{80}$.

Po II wojnie światowej i powrocie zbiorów PAU do jej siedziby przy ulicy Sławkowskiej w pierwszej kolejności przeprowadzono skontrum całego zasobu, a następnie przystąpiono do zewidencjonowania przedwojennych nabytków. W tym celu zaprowadzono księgę ze spisem dokumentów, która miała rejestrować dyplomy nie objęte Katalogiem Czubka ${ }^{81}$. Równocześnie przeprowadzono meliorację zbiorów rękopiśmiennych i wyłączono $\mathrm{z}$ nich dyplomy pergaminowe pominięte uprzednio przez Czubka. W efekcie tych prac do 5 marca 1952 r. zbiór dokumentów pergaminowych powiększył się o 226 jednostek. W dalszym ciągu nie zachowywano jednak konsekwencji przy włączaniu nabytków do tego wyodrębnionego zbioru. Trafiały tu zarówno dokumenty pergaminowe, jak i papierowe. Przy 66 dokumentach zapisano, iż pochodzą z kopert profesora Władysława Semkowicza. Adnotacja ta sugeruje, że Władysław Semkowicz, albo wdowa po nim Jadwiga Semkowiczowa, przekazali do Biblioteki PAU kolekcję 44 dokumentów pergaminowych i 22 papierowych. Dopiero uważna lektura sprawozdań z działalności PAU pozwala stwierdzić, że pochodziły one z przedwojennego zasobu Biblioteki PAU, a profesor Semkowicz w czasie okupacji niemieckiej opracował do nich katalog kartkowy ${ }^{82}$.

W wyniku decyzji władz państwowych w 1952 r. PAU została zmuszona do zawieszenia działalności, a cały jej majątek i wszystkie aktywa przejęła nowo utworzona instytucja naukowa, Polska Akademia Nauk z siedzibą w Warszawie. W chwili przejęcia Biblioteki PAU przez nowego właściciela jej zasób nie był w całości skatalogowany i zewidencjonowany. Wciąż na opracowanie czekały obszerne spuścizny Franciszka Ksawerego Wolańskiego, ks. Jana Ambrożego Wadowskiego i ks. Jana Fijałka.

W 1953 r. do zbioru dyplomów włączono światłodruk traktatu o wieczystej przyjaźni zawarty między sułtanem Muradem III Fermen i królem polskim Stefanem Batorym z r. 1577, pozyskany w oparciu o oryginał przechowywany w Archiwum Akt Głównych w Warszawie i ofiarowany do krakowskich zbiorów przez wybitnego turkologa prof. Władysława Zimnickiego ${ }^{83}$. W r. 1976 dr Krystyna Pieradzka

${ }^{79}$ Bibl. Nauk. PAU i PAN, dok. 605, 606.

${ }^{80}$ Bibl. Nauk. PAU i PAN, dok. 480, 484.

${ }^{81}$ Bibl. Nauk. PAU i PAN, Spis dyplomów nr 331-568, bez sygn.

${ }^{82}$ Sprawozdanie z czynności i wydawnictw P.A.U. od czerwca 1939 do lipca 1945, „Rocznik PAU 1939-1945", s. 26.

${ }^{83}$ Bibl. Nauk. PAU i PAN, dok. 558. 
przekazała do zbiorów Biblioteki PAN niemieckojęzyczny dyplom z r. 1428, wyłączony ze spuścizny zmarłego w $1965 \mathrm{r}$. Jana Dąbrowskiego, profesora historii $\mathrm{UJ}^{84}$. W 1979 r. antykwariusz lwowski Feliks Ścibałła przekazał do zbiorów Biblioteki PAN dokument z r. $1561^{85}$.

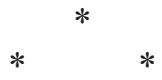

Wśród nabytków pozyskanych jeszcze w XIX w. do zbiorów Akademii są dokumenty pergaminowe, które do tej pory nie zostały wnikliwie przebadane. Są to trzy dokumenty odzyskane z opraw piętnastowiecznych ksiąg ziemskich i grodzkich sieradzkich. Wiedza na temat losów tych dokumentów jest fragmentaryczna. Największa i najdotkliwsza luka dotyczy okresu od zdemontowania ich z ksiąg ziemskich i grodzkich sieradzkich w II poł. XIX w. aż do momentu przekazania Akademii. Stosunkowo dobrze znane są dzieje samego zespołu ksiąg ziemskich i grodzkich sieradzkich, nawet z najbardziej dramatycznego okresu wojen szwedzkich. Archiwariusz sieradzki Antoni Pstrokoński, sporządzający na początku XIX w. rejestr ksiąg ziemskich i grodzkich, relacjonował, że w r. 1656 zostały one ewakuowane do Częstochowy, zaś 27 kwietnia 1800 r. ocalały z pożaru Sieradza. Do lat dwudziestych XIX w. przechowywane były pod wieżą kolegiaty w Sieradzu. W latach 1826-1836 w wyniku porządkowania zasobów archiwów akt dawnych i ich reorganizacji zespół ksiąg ziemskich i grodzkich sieradzkich został przeniesiony do archiwum trybunału cywilnego w Sieradzu, zaś w 1848 r. podjęto decyzję o przeniesieniu ich z Sieradza do Kalisza. Kłopoty finansowe związane z utrzymaniem sieci archiwów staropolskich sprawiły, że w latach osiemdziesiątych XIX w. zdecydowano o zgromadzeniu ich w Archiwum Głównym w Warszawie ${ }^{86}$. W latach 1848-1864, gdy prowadzono prace nad opracowaniem pomocy archiwalnych w postaci sumariuszy i skorowidzów, zdemontowano pergaminowe oprawy z kilkunastu ksiąg sieradzkich i szadkowskich, ponieważ były bardzo poważnie uszkodzone, silnie zdeformowane, zabrudzone i wytarte, i zastąpiono je nowymi, tekturowymi oprawami ${ }^{87}$. Jedynie dzięki wiedzy, wprawnemu oku, a być może wyłącznie intuicji nieznanego archiwariusza, badacza lub kolekcjonera zdemontowane pergaminowe karty ocalały. Stan ich zachowania był tak zły, że praktycznie uniemożliwiał ich odczytanie. Mimo to ów nieznany badacz i kolekcjoner zachował je i przekazał do zbiorów AU. Szczątkowy stan zachowania niektórych z tych kart sprawił, iż długo pozostawały nieodczytane i nieopracowanie. Jan Czubek wydobył z nich jedynie trzy karty, które stanowiły fragmenty dyplomów pergaminowych i włączył do

${ }^{84}$ Bibl. Nauk. PAU i PAN, dok. 623.

${ }^{85}$ Bibl. Nauk. PAU i PAN, dok. 616.

${ }^{86}$ A. Wajs, Historyczne $i$ wspótczesne pomoce archiwalne do akt ziemskich i grodzkich województwa sieradzkiego w AGAD, „Miscellanea Historico-Archivistica”, t. 10: 1999, s. 78-80.

${ }^{87}$ A. Wajs, Historyczne $i$ wspótczesne pomoce archiwalne, s. 80. 
wyodrębnionego zespołu 330 dokumentów pergaminowych i papierowych, lecz miał problem ze sporządzeniem ich opisu. Stan dokumentów pozwalał jedynie na wymienienie niektórych wzmiankowanych w nich osób ${ }^{88}$. Nieczytelność dokumentów sprawiła, że K. Dziwik pominął je całkowicie przy opracowaniu Katalogu dokumentów pergaminowych. Inni bibliotekarze mieli również problemy z odczytaniem $\mathrm{z}$ tych dokumentów, a nawet ze stwierdzeniem, w jakim języku zostały spisane. W 2014 r. Biblioteka przeprowadziła konserwację tych dokumentów, którą wykonały doświadczone konserwatorki: Anita Bogdanowicz i Krystyna Dajnowicz-Rolińska. Prace konserwatorskie rozpoczęto od wstępnego prostowania dokumentów pod lekkim obciążeniem, następnie oczyszczono mechanicznie lica i odwrocia dokumentów. Po oczyszczeniu przystąpiono do uelastycznienia i wyprostowania pergaminu, $\mathrm{w}$ dalszej zaś kolejności uzupełniono większe ubytki ${ }^{89}$. W efekcie tych prac dokumenty pergaminowe stały się lepiej czytelne, co pozwoliło dokładniej poznać ich treść, którą poniżej prezentujemy.

\section{ANEKS}

1406, maj, Praga

Anno Nativitatis eiusdem millesimo quadragentesimo sexto, indicione [...] mensis May, hora vesperorum vel quasi, pontificatus sanctissimi in Christo patris domini Innocency [...] pape [...] anno secundo in capella B[etleem ...] ecclesie sancti Philipi [et Jacobi] apostoli maioris civitatis Pragensis.

Instrument notarialny sporządzony na prośbę Stanisława ze Znojma, profesora teologii i dziekana wydziału teologicznego Uniwersytetu Praskiego i Andrzeja Brody bakałarza teologii, publikuje postanowienie arbitrów i rozjemców w sporze doktrynalnym na temat konsubstancjacji między Stanisławem ze Znojma a Janem ze Szczekna.

\section{J. łac.; wymiary: $26,6 \times 29 \mathrm{~cm}$.}

Pieczęć: brak.

Noty: z przodu: „Quaesitum cum Szydłowski”; - na odwrocie: „Na proll.3”, „, Castrensi Terre ...” (XV w. ); „Quesivit pro ... 1558 die 6us Martii”; „Quaesivit per G. Dluzewski pro M. Szypkowski nota ... 1757".

Stan zachowania: dokument zachowany fragmentaryczne; obcięta dolna część oraz prawy róg dokumentu; zaplamiony, mocno wytarty.

Proweniencja: do II poł. XIX w. stanowił oprawę księgi ziemskiej sieradzkiej z lat 1402-1409 (AGAD, Księgi ziemskie sieradzkie, t. 3).

Sygnatura: dok. 17.

${ }^{88}$ Katalog rękopisów AU w Krakowie, Dodatek I, oprac. J. Czubek, Kraków 1912, s. 59, 71,75 .

${ }^{89}$ A. Bogdanowicz, K. Dajnowicz-Rolińska, Dokumentacja konserwatorska [dokumentów pergaminowych sygn. 5, 7, 17, 61, 75, 106], Kraków 2014, msp. 
1432, 15 lipca, Rzym

Datum apud Sanctum Petrum millesimo quadragentesimo tricesimo secundo, Idus July, pontificatus nostri anno secundo.

[Eugeniusz IV papież nakazuje wprowadzić] Mikołaja [Chebdę z Niewiesza, kanonika gnieźnieńskiego] włocławskiego i kruszwickiego na kantorię [poznańską wakującą po awansie na prepozyturę poznańską] Wyszoty [z Górki] i śmierci [Jana z Wywli].

J. łac.; wymiary: 53,8×30,2+3,6 cm (obecnie zakładka rozprostowana co daje wymiary: $53,8 \times$ $33,8 \mathrm{~cm})$.

Pieczęć: brak.

Noty: na odwrocie: „Terre Siradien. 1463 ad 1475” (XV w.), ,332”.

Regest: Bullarium Poloniae, t. 5, ed. I. Sułkowska-Kuraś, S. Kuraś, Romae-Lublin 1995, nr 150.

Stan zachowania: dokument zachowany fragmentaryczne; wyrwana środkowa część dokumentu; wytarty; zabrudzony.

Proweniencja: do II poł. XIX w. stanowił oprawę księgi ziemskiej sieradzkiej z lat 1463-1475 (AGAD, Księgi ziemskie sieradzkie, t. 12).

Sygnatura: dok. 61

[1523-1534]

Instrument notarialny poświadczający, że Maciej Rogala ze Stachlewa, kanonik łęczycki udziela Stanisławowi, synowi Urbana z Gężyna, klerykowi diecezji krakowskiej uprawnień wicekomesa i deleguje go do mianowania notariuszy publicznych apostolica auctoritate.

J. łac.; wymiary: $32 \times 46 \mathrm{~cm}$.

Pieczęć: brak.

Noty: z przodu: „Quaesit per Mycielski a 15 February 1775 ”; - na odwrocie: „1475 et $6^{\text {to” }}$ (XV w.), „Quaesit per Szydłowski”, „Quesit Dłurzewski pro...”

Proweniencja: do II poł. XIX w. stanowił oprawę księgi grodzkiej sieradzkiej z lat 1475-1477 (AGAD, Księgi grodzkie sieradzkie, t. 19).

Stan zachowania: dokument zachowany fragmentaryczne; obcięta dolna część dokumentu oraz prawy i lewy margines; mocno wytarty, zabrudzony.

Uwagi: datacja ustalona w oparciu o lata pontyfikatu papieża Klemensa VII.

Sygnatura: dok. 75 


\title{
ELŻBIETA KNAPEK
}

\author{
THE PROVENANCE OF THE SET OF PARCHMENT DOCUMENTS FROM \\ THE SCIENTIFIC LIBRARY OF THE POLISH ACADEMY OF ARTS AND SCIENCES \\ AND THE POLISH ACADEMY OF SCIENCES IN CRACOW
}

\begin{abstract}
Summary
The beginnings of the parchment documents collection of the Scientific Library of the Polish Academy of Arts and Sciences and the Polish Academy of Sciences date back to mid $19^{\text {th }}$ century, that is to the time when the whole library collection started being created. It was established mainly thanks to the endowments donated by the members of the Cracow Scientific Society, later Academy of Arts and Sciences. Apart from that, the benefactors were Cracow's burghers, clerks, priests, doctors, publicists and even students, there were also landowners. Their names were meticulously registered in the books of endowments to the Cracow Scientific Society from 1856 - 1871 and to the Academy from 18871890. Initially, the parchment diplomas were not separated from the rest of the manuscripts. In 1906 Jan Czubek was preparing a publication of the second part of the Catalogue of the manuscripts belonging to the Academy of Arts and Sciences and he came up with an idea to create a separate collection of parchment documents. Three parchment documents from the $15^{\text {th }}$ and $16^{\text {th }}$ century are very interesting. Until mid $19^{\text {th }}$ century they constituted the covers of the Sieradz land registers. After they were removed from the registers, despite being considerably damaged, they were preserved by an anonymous but provident collector and donated to the Academy of Arts and Sciences and its collection. In 2014 they were restored, so today we can identify two notarial documents and one papal bulla, unknown to the historians.
\end{abstract}


